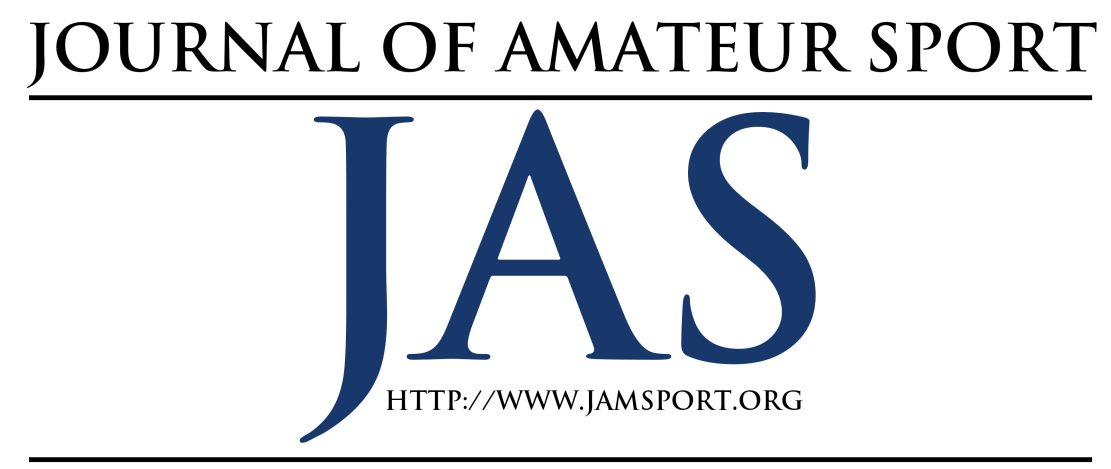

\title{
Sport Spectator Behavior as a Moral Issue in College Sport
}

\author{
Andy Rudd \\ Belmont Abbey College
}

\begin{abstract}
Spectator aggression continues to be a serious problem in American college athletics. However, despite the magnitude of this problem, fan abuse has not received the same level of concern (i.e., promotion of sportsmanship and fair play) as "winningat-all-costs" perpetrated by athletic participants. In response, the author argues that perhaps many in the sport milieu do not consider fan behavior as a moral issue (i.e., actions that are harmful to others) and therefore unworthy of more serious consideration. As a result, the purpose of this study was to explore the types of spectator abuse inflicted upon college athletes as well as assessing the emotional impact. The results of this study showed that college athletes do indeed experience a variety of insults and harassment. However, findings also indicated that athletes are generally emotionally unaffected by the abuse. The contradictory nature of this finding is discussed.
\end{abstract}

S port spectator aggression is a serious problem across a variety of sports, levels, and countries (Gubar, 2015; Wakefield \& Wann, 2006; Wann, Haynes, McLean, \& Pullen, 2003; Wann, Melnick, Russell, Pease, 2001). Of particular and growing concern in the United States is spectator aggression in college athletics. This is evidenced by former NCAA president, Myles Brand (2008), who stated, "Campuses increasingly have student sections in football and basketball that have taken on the role of ensuring a home court advantage with zealous enthusiasm that sometimes moves from rowdy support to over-the-top vulgarity and violent action" (Brand, 2008, n.p.). Brand (2008) stated further, "These behaviors represent a threat to the integrity of intercollegiate athletics....It's time to address the rising problem" (n.p.). 
In addition to Brand's strong assertions, there is a variety of anecdotal and empirical research to support the existence of spectator aggression in college athletics. Anecdotally, Ngo (2012), for example, reported a variety of spectator aggression at college football games such as trash talking, booing, throwing beer cans, and harassing cheerleaders. As well, college basketball fans insult and harass players to the point that players such as Oklahoma State's Marcus Smart attacked a Texas Tech fan in the stands. The fan, Jeff Orr, acknowledged that he "enjoyed his moment of getting into Smart's head" (Monteiro, 2014, n.p.) (see also, Wahl, 2008). Empirically, Rudd and Gordon (2010) found that 52 out of 137 college student basketball fans self-reported the use of various forms of heckling and harassment towards the opponent.

Additionally, a study by Rudd (2016) revealed that among a sample of 221 college students, the majority "agreed" or "tended to agree" that it is fair to heckle opposing players, yell at the referee or umpire, or ridicule the rival teams.

Spectator aggression, however, has not been addressed equally to that of the winning-at-all-costs behaviors committed by athletic participants. For example, major interscholastic sport organizations such the National Collegiate Athletic Association (NCAA), the National Association of Intercollegiate Athletics (NAIA), and the National Federation of State High School Associations (NFHS) all list and encourage sportsmanship as an important value within competition (Champions of Character; NCAA Core Values; The Case for High School Activities) but give little or no attention to spectator behavior. In addition, numerous scholars and educators have written on the importance of sportsmanship and fair play among athletes (Arnold, 1992; Clifford \& Feezell, 1997; Lumpkin, Stoll, \& Beller, 2003; Simon, Torres, \& Hager, 2015) whereas few, if any, have done so in the context of sport spectatorship.

This lack of attention suggests that many in the sport milieu may not consider spectator aggression to fall within the same realm of winning-at-all costs, or believe that fans have a responsibility to practice sportsmanship in a manner equal to athletic competitors. The purpose of this article, therefore, is to establish spectator aggression as a moral issue in sport that should be viewed equally to winning-at-allcosts in athletic competition. It is hoped that doing so will stimulate sport administrators to consider fan behavior more seriously. As well, perhaps establishing spectator aggression as a moral issue will evoke more educational and philosophical writings on the spectator aggression problem, which in turn, will create more awareness and problem solving to address this important issue.

To support the case that spectator aggression violates morality and is therefore a moral issue, a study was conducted with a convenience sample of NCAA Division II athletes. The key research questions to be answered were: 1) What is the nature of the 
spectator aggression that is directed towards college athletes? 2) To what extent do various forms of spectator aggression emotionally hurt college athletes? 3) To what extent do various forms of spectator aggression have a positive or negative impact on college athletes' athletic performance? The answer to these questions will ultimately help determine if spectator aggression is a moral issue. However, before answering these questions, a number of key constructs are explained including spectator aggression, ethics, sportsmanship, and the notion of sport as a valued human practice. Subsequent to this section will be the study's methodology, results, and discussion.

\section{Key Supporting Concepts Spectator Aggression}

Aggression has generally been defined as involving the intention to harm or injure another person (Baron \& Richardson, 1994; Branscombe \& Wann, 1992; Shields \& Bredemeier, 1995). Coakley (2009 has added that aggression may involve physical or verbal actions that are intended to "dominate, control, or do harm to another" (p. 197). More specific to sport, Wann, Carlson, and Schrader (1999) posit that sport spectator aggression can be divided into two types: hostile and instrumental. The former involves acts of violence or harm motivated by feelings of anger. For example, a spectator may cast obscenities or throw objects at a referee for making what is perceived to be a bad call. In contrast, instrumental aggression pertains to harmful actions that are intended to yield a particular result. For instance, a spectator may shout derisive comments to an opposing player with the goal of diminishing their concentration and performance.

Therefore, in the sport context, spectator aggression essentially involves harmful verbal or physical actions towards others in the sport milieu including opposing players, coaches, and game officials. Further, spectators may act aggressively for either hostile or instrumental reasons. However, for clarification, the purpose of this study is not to assess intentionality. Rather, the overarching purpose of this study is to determine if college athletes are emotionally affected by spectator aggression regardless of the type of aggression (i.e., hostile or instrumental).

\section{The Nature of Ethics}

According to Frankena (1973), ethics involves thinking about morality or moral problems. Morality is essentially concerned with how our actions, motives, and intentions affect other people (Lumpkin, Stoll, \& Beller, 1994). Ethics, therefore, involves reasoning about the rightness or wrongness of one's actions or how one "ought" to act in order to avoid hurting others (DeSensi \& Rosenberg, 1996; Morgan, Meier, \& Schneider, 2001). Lumpkin et al. (1994) have referred to this reasoning process as moral reasoning, which importantly, will be affected by what one 
values: the moral or the nonmoral. Moral values are those values involving actions, motives, and intentions towards other people (Lumpkin, Stoll, \& Beller, 2003). Moral values are therefore critical to human relationships and when violated may likely cause harm (Lumpkin et al., 1994). Thus, ethical situations arise when harm may come to another individual as a result of violating a moral value. Prime examples of moral values include honesty, justice, beneficence, and responsibility (Lumpkin et al., 1994).

In contrast, nonmoral values are based on things that have an extrinsic quality such as money, power, fame, and winning (Frankena, 1973; Lumpkin et al., 1994).

Nonmoral values by themselves do not have a moral quality because they are merely things. However, what one does to obtain a particular nonmoral value may induce an ethical problem and the use of moral reasoning. For example, the extent that an athlete values winning may impact whether or not he or she will play fairly or respect their opponent. That is, the individual may value winning to the point that he or she will cheat to win or perhaps bring harm to their opponent. Similarly, in the case of college sport spectators, what is valued likely impacts their moral reasoning in relationship to the opposing team. Spectators who cast abusive insults towards opposing players likely value winning over moral values such as respect or beneficence (not doing harm).

\section{Expanding the Concept of Sportsmanship to Sport Spectators}

Perhaps synonymous with ethics in sport is the concept of sportsmanship as a result of its moral underpinnings. Although there are a variety of definitions, most point to the upholding of moral values. Rudd and Stoll (1998) posited that sportsmanship includes the moral values of responsibility, fairness, and respect for one's opponent. Clifford and Feezell (1997) maintain that sportsmanship is "excellence of character" (p. 15) with the moral value of respect at its core. Arnold (1984) proposed a multidimensional view of sportsmanship which includes amicability (social union view), generosity and magnanimity (pleasure view), and compassion (altruistic view).

In sum, these definitions suggest that sportsmanship is the concrete display of acting ethically in sport. Or, as Clifford and Feezell (1997) suggested, sportsmanship is the display of virtuous behavior. Furthermore, the notion of sportsmanship gives support to the idea that there is indeed a morality in sport. For without sportsmanship, the ethos of sport becomes purely about winning and doing whatever it takes to do so. This latter type of model often results in the use of cheating, as well as harming and disrespecting one's opponent (i.e., winning at all costs).

Sportsmanship can also be thought of in terms of the "good sports contest" (Fraleigh, 1982, p. 186) which is not only germane to athletic competitors but also sport spectators. According to Fraleigh, the 
good sports contest can only occur when all athletic participants are able to fairly contest one another. That is, when all competitors abide by the rules of the given sport. Contrariwise, when participants intentionally break rules to gain an advantage, a fair contest no longer exists and thus makes it impossible to determine a legitimate winner. $\mathrm{n}$ a similar vein, Pearson (1973) posited that the purpose of an athletic contest is to test one's skills against their competitors in order to determine who is the more skilled individual or team.

Athletic competitors compete unethically (or unsportsmanlike) when they intentionally defy the purpose of the athletic contest (i.e., to test one's skill against their competitor's skill in order to determine who is more skillful) (Pearson, 1973).

Fraleigh's (1982) and Pearson's (1973) ideas about skill testing and the good sports contest can easily be applied to sport spectator aggression. For, sport spectators who act physically or verbally aggressive towards opposing players are not upholding the notion of a good sports contest where athletic competitors are able to test their skills. Rather, aggressive sport spectators inflict various forms of physical or verbal harm that can be intended to prevent participants from competing at their highest level (i.e., instrumental aggression). As Pearson (1973) proposed, sport competitors act unethically when they intentionally violate the intended purpose of the particular sport: to determine who is the more skilled team or player. Sport spectators, then, behave unethically or unsportsmanlike when acting aggressively towards opposing players, which can in turn, prevent equal skill testing.

In addition to Fraleigh (1982) and Pearson (1973), Clifford and Feezell's (1997) notion of sportsmanship as respect for one's opponent is also applicable to sport spectators. Clifford and Feezell maintain that if athletic competitors value competition and the opportunity to excel, then it is only logical that participants should want good opponents. As such, one's opponent should be respected and valued rather than viewed as an enemy to be humiliated and destroyed. Applied to sport spectatorship, spectators should want to watch their team challenged by a worthy opponent, which in turn results in a good sports contest. This, however, is unlikely to occur if spectators act with hostile and instrumental aggression towards opposing players.

\section{Sport as a Valued Human Practice versus Winning at All Costs}

The previous two sections established that there is an ethical basis to sport that can be displayed through sportsmanship. However, as mentioned earlier, many in the sport milieu may compete under an alternative competitive model known as winning-at-all-costs. Arnold (1992) suggested that this latter model of competition is the byproduct of what he calls the "sociological view of sport" ( $p$. 240 ) in which the purpose of competition is 
to achieve a variety of extrinsic goals such as winning, money, fame, and prestige. Arnold maintains that when extrinsic goals become the focal point of competition, competitors may do whatever it takes to win, including cheating, violence, and other forms of gamesmanship, which amounts to a winning-at-all-cost mentality.

However, contravening the winning at all costs ethos in sport, Arnold (1992) has offered an alternative view. Arnold posits that sport may be considered as a culturally valued human practice much like other valued human practices such as medicine, engineering, farming, or architecture (Arnold, 1992). When sport is viewed as a valued human practice, it means that each competitor considers him or herself as a member of that particular sport. As a member, one willingly agrees to be measured and evaluated in accordance to the particular rules and standards of excellence within a given sport (Arnold, 1992). Sport, then, is pursued for the sake of participating and attempting to achieve the internal goals of sports (e.g., giving a scoring pass in soccer, making a great angle shot in tennis, or a spectacular run in American football) rather than for extrinsic rewards such as winning and money (Arnold, 1992). Arnold also adds:

Furthermore, every practice, if it is to remain true to itself and not be corrupted by influences or pressures external to it, requires a certain kind of relationship between those who participate in it, whether they like one another or not, or whether, as in many instances of sport, they find themselves opposed to one another in competition. Unless the participants in a practice see one another with respect and as being common guardians of the values inherent in the practice they are pursuing, the practice itself is likely to suffer and perhaps fall victim to the unprincipled and the unscrupulous ( $p$. 239).

Arnold, therefore suggests that in order to avoid the desire for extrinsic rewards and the winning-at-all cost mentality that may follow, the moral values of justice, honesty, and courage be fostered and integrated into the ethos of sport. Specifically, justice will establish fair treatment and play among competitors. Honesty will create a sense of trust between opponents and courage will engender the ability to risk harm to oneself when it is necessary to uphold and protect the internal goals and values that make-up the practice of sport.

In conclusion, Arnold's (1992) view of sport a valued human practice provides the necessary framework for legitimizing the practice of ethics and sportsmanship by both athletes and spectators. For, as Arnold asserted in the above quotation, when athletes view their participation in sport as a member of a valued human practice, they will then do all they can to preserve the integrity of that practice regardless if they are in opposition to one another. On the other hand, when competition becomes imbued with a desire towards the extrinsic 
(e.g., winning, money, power, etc.), a winning at all costs ethos may emerge, which may also involve hatefulness towards one's opponent. It is this latter model that has perhaps fueled much of the spectator aggression in college athletics.

\section{Method}

\section{Design}

This study utilized a descriptive nonexperimental design. Such a design is appropriate when the researcher is interested in describing a given phenomenon that is related to a particular attitude, belief, or behavior (Johnson \& Christensen, 2012). In the case of this particular study, the researcher sought to describe the emotional impact of spectator aggression on college athletes and to describe the nature of the aggression. A combination of quantitative and qualitative data was collected for the description (see below).

\section{Data Collection}

A short questionnaire (six questions) was developed to assess the emotional impact of spectator aggression (harassment and insults) on college athletes and to obtain information about the nature of the aggression (see Appendix A). The questionnaire included five closed-ended questions and one open-ended question to collect qualitative data (see Table 1 for responses to questions 1-5).

The closed-ended questions had either two or three response options depending on the nature of the particular question. For example, question \#3 states, "To what extent did the insults or harassment hurt you emotionally?" The following response options are then: Not Hurtful, Hurtful, and Very Hurtful. For clarification, although some research has suggested the use of anywhere from 4-11 response options (Johnson \& Christensen, 2012), Frary has pointed out that too many response options can confuse the responder and therefore the number of response options should depend more on the nature of the question. Thus, it is believed that it was sufficient to have two to three response options for the particular questions. Furthermore, the need to have a wider range of response options is more of a consideration for summative scales in order to create enough variability in responder scores (Thorndike, 1997). However, as mentioned, the questionnaire used for this study is not summative.

Regarding reliability and validity, because the questionnaire was not designed as a summative scale, internal consistency and factor analysis were not conducted. These are common methods for providing reliability and validity evidence for attitude scales (Johnson \& Christensen, 2012; Thorndike, 1997). Instead, each question was unique to the others and was therefore analyzed individually. The validity of the questions is based on their development from supporting literature concerning spectator aggression (Gubar, 2015; Ngo, 2012; Rudd \& Gordon, 2010; Wann et al., 1999). 


\section{Participants/Procedure}

After being provided a list of studentathlete email addresses by the athletic director of the respective college, the questionnaire was electronically administered (using a survey software program) to a convenience sample of 287 male and female college athletes competing for a NCAA Division II college in the Southeast. Specific sports were men's baseball ( $n=92)$, men's basketball $(n=15)$, women's basketball $(n=19)$, men's soccer $(n=55)$, women's soccer ( $n=42)$, women's softball $(n=32)$, men's volleyball $(n=14)$, and women's volleyball $(n=18)$. These specific sports were targeted on the basis that they involve settings where spectators can be close enough to the athletes to have a psychological impact as a result of loud abusive chanting and harassing. A total of 108 athletes (males $=58$; females $=50$ ) responded anonymously to the questionnaire (37.6\% response rate) which included men's baseball ( $\mathrm{n}=27)$, men's basketball ( $\mathrm{n}=9)$, women's basketball $(\mathrm{n}=8)$, men's soccer ( $n=17)$, women's soccer $(n=18)$, women's softball ( $n=16)$, men's volleyball $(\mathrm{n}=5)$, and women's volleyball $(\mathrm{n}=8)$.

\section{Data Analysis}

IBM SPSS version 22.0 was employed to run descriptive analyses in the form of a frequency distribution on the closed-ended questions (1-5). These analyses were used to determine the percentage of athletes that were choosing the various response options (see Table 1). In addition, a content analysis (identification of emerging patterns or themes) (Creswell, 1998; Patton, 1987) was conducted for question \#6 which was an open-ended question used to stimulate qualitative responses concerning the types of harassment or insults college athletes experienced while competing.

\section{Results}

\section{Quantitative Data}

Question \#1 asked how many of the athletes had experienced being harassed or insulted while competing as a college athlete. Of the 108 that responded, (52.8\%) said "no "compared to $(47.2 \%)$ that said "yes." The latter group $(\mathrm{n}=53)$ then responded to the five remaining questions (four of which were quantitative) related to experiences with spectator aggression. As seen in Table 1, the majority $(72.5 \%)$ reported being harassed or insulted "not often" whereas a combined $27.5 \%$ indicated "often" or "very often" (question \#2). Additionally, $82.4 \%$ did not find fans' insults or harassment "hurtful" compared to $17.6 \%$ that found the abuse to have a hurtful impact (question \#3).

Regarding the impact of fan abuse on performance, the majority $(66.7 \%)$ indicated that insults and harassment did not decrease their athletic performance, while an additional $33.3 \%$ reported that insults and harassment did decrease performance "somewhat" (question \#4). Alternatively, a sizeable number of athletes reported that harassment or insults caused them to 
improve their performance "a lot" (15.7\%) or "somewhat" (56.9\%) whereas $27.5 \%$ indicated "not at all" (question \#5).

\section{Qualitative Data}

Of the 51 athletes that said "yes" to question \#1, there were 34 athletes that provided qualitative responses to question \#6, which asked the athletes to provide examples of fan harassment or insults. After reading and carefully examining all of the responses, six themes emerged related to the types of harassment or insults experienced. These themes include: 1) physical characteristics, 2) playing ability, 3) parents yelling, 4) prove the fans wrong/play harder, 5) use of player's name or number, and 6) miscellaneous forms of harassment/insults.

In the identification of these themes, it is important to note that there are no hard scientific principles, laws, or assumptions that must be met in qualitative data analysis (Patton, 1987). Rather, according to Patton (1987) qualitative researchers "must rely on their own intelligence, experience, and judgment" (p. 154) when analyzing qualitative data. Similarly, Creswell (1998) stated, "Undoubtedly, no consensus exists for the analysis of the forms of qualitative data" (p. 140). Therefore, the identified themes were based on the interpretation of the author. To provide trustworthiness and verification of the proposed themes, verbatim quotes have been provided for the reader so that the identified themes are verifiable and trustworthy. According to
Johnson and Christensen (2012), the use of low inference descriptors (verbatim) is one method for strengthening interpretive validity.

What follows next are the listing of each theme along with the number of statements that were associated with it. For clarification, each statement is from a different athlete. Therefore, a theme with seven statements equates to seven different athletes. In order to illustrate the nature of each theme, two verbatim statements are provided. Note that some responses were rich to the extent that they could be placed within more than one theme.

Physical characteristics. The first theme represents a total of seven different statements that mention fans making insulting remarks about some aspect of a player's physical appearance. For example, one athlete said, "One time during a volleyball game this guy in the stands was making fun of my forehead haha." Another said, "In my first collegiate game at [name of place omitted] last season, I was getting insulted about being foreign and having red hair. I ended up messing up the corner kick right in front of their fans haha."

Playing ability. The second theme represents a total of 12 different responses that involved fans deriding players for making a mistake or their playing ability. This theme captured the most prevalent number of responses related to harassment or insults by fans. For instance, a player said "People I don't know on the other team yelling my name or number, telling me you 
suck, nice ass, and don't mess up." Another simply replied with "Calling names, yelling air ball if I miss a shot. I've had parents yell at me, etc."

Parents yelling. The fourth theme represents five different responses involving parents yelling out forms of insults and harassment to opposing players. For example, one player said,

I have been given dirty looks by parents on the opposing team who are watching the game. I have also heard parents yell at the other team to "hit her hard" or "make sure she's scared when you run at her."

Additionally, another athlete stated, "I've had parents complain about me when I pitch and it puts a fire inside me and makes me throw better."

Prove the fans wrong/play harder. The fifth theme represents eight different statements that related to playing harder and proving fans wrong when receiving insults or harassment. For instance, an athlete said, "You will hear them laugh and jeer, but you have to use it as a way to make you perform better. Prove them wrong almost." Another player said,

[team name omitted] softball team were making comments at me during the middle of a game at conference tournament. They kept saying stuff like 'You aren't really freshman of the year,' so I got really hyped and played with some cocky confidence and it made me want to play better.
Use of player's name or number. The sixth theme represents seven statements that pointed to the use of players' names or numbers as a form of harassment or insult. One player said, “....if I make a bad pass a spectator would say something like "nice one" or "great job number 7." A different player said, "They find our name and call you out personally."

\section{Miscellaneous forms of}

harassment/insults. Lastly, there were ten different unique statements that were difficult to capture thematically. For example, one athlete stated, "Some spectators get very personal and look stuff up about you and your family." Another player said, "Racial slurs are the only insults I get at games."

\section{Discussion}

The purpose of this study was to substantiate the proposition that spectator aggression is a moral issue in college athletics as well as inconsistent with sportsmanship and the practice view of sport. The impetus for making such an argument is to bring more serious attention to sport administrators who as Brand (2008) stated: "look the other way" in the interest of maintaining strong fan support (n.p.).

As explained earlier, ethical problems involve the violation of moral values and harm to others (Lumpkin et al., 1994). However, most athletes did not report being emotionally hurt by spectators' insults or harassment. Also, the majority did not find insults and harassment to decrease playing 
ability. In contrast, many of the athletes felt that spectators' insults or harassment could, to some degree, improve performance.

Responses, then, suggest that most athletes from this study's sample are not emotionally or negatively affected by spectator abuse and therefore it would seem difficult to identify spectator behavior in college sport as an ethical problem. However, a conflict in this appraisal arises when considering the nature of the various insults and harassment experienced by college athletes. As shown in the results section, athletes experienced a variety of insults specifically related to one's playing ability and physical appearance. Therefore, is it not unethical when fans make derogatory or mean spirited comments such as telling a player that they "suck" or when they are ridiculing players for the color of their hair, shape of their forehead, or making racial slurs? As such, although many athletes indicated that fan insults and harassment are not hurtful, it does not necessarily mean that the nature of the fan abuse is morally acceptable. As Shields and Bredemeier (1995) noted, evaluating morality requires an understanding of the intentions behind the action. Actions with harmful intent violate morality (Lumpkin et al., 1994). For example, Person A intentionally and without provocation shoots Person B, who is wearing a bulletproof vest. Because the bullet hits the vest and does not cause harm to Person B does not mean that Person A is cleared of immorality. Thus, it may be argued that although many athletes claim they are not affected by fan abuse, there is still an ethical issue at hand when fans intentionally desire to cause emotional harm to competing athletes (see Wann et al, 1999).

It is also important to consider the mechanisms that may allow many college athletes to be emotionally unaffected by fan abuse (at least judging by this sample's responses). For, if an individual was ridiculed or harassed while simply walking to their car, would they not feel insulted and upset? More than likely, the answer is, "Yes." What is it then about the sport context that causes many athletes to become impervious to verbal abuse? The answer to this question may largely rest on our North American sport society's extreme emphasis on winning.

Sage and Eitzen (2016) posit that North Americans place an enormous premium on winning (see also, Eitzen 1999; May, 2001). They maintain that there is typically no other conception of success in sport but to win (Sage \& Eizten, 2016). As such, college and professional coaches are frequently fired for not winning which in turn creates great pressure to win and avoid being deemed a failure (Sage \& Eitzen, 2016; USTA Hires LSU's Wilson, 2015). Athletes across all levels of sport are then scorned and belittled for failure to win (Eizten, 1999; Sage \& Eitzen, 2016). This type of sport culture ultimately leads to the fostering of certain types of values that are believed to be instrumental in winning. Sage and Eitzen (2016) point to the values of work ethic and 
sacrifice as two critically important values espoused by coaches. It is believed that the high possession of these two values is the difference between winning and losing (Sage \& Eitzen, 2016).

In a similar vein, Coakley (2009) posits that elite level athletes are socialized into accepting four key norms that make-up the "sport ethic" (p. 163) which includes: 1) dedication to the sport above all else, 2) striving for distinction, 3) accepting risks and playing through pain, and 4) no acceptance of obstacles to prevent winning. According to this theory, athletes wishing to reach elite levels of sport (e.g., college and professional), must adhere to the norms of the sport ethic (Coakley, 2009). Coakley (2009) suggests that conforming to the sport ethic becomes dangerous when athletes mistakenly overconform. This occurs when an athlete goes beyond the accepted norm of being a competitive athlete. For example, an athlete may "strive for distinction" by using performance enhancing drugs or overtraining.

In sum, there is reason to believe that athletes may be socialized or taught by coaches, parents, and teammates that there is a certain type of mentality and value system that must be maintained in order to be competitive and remain a participant of elite level sport. Part of this norm system is that one must be mentally tough in competition, which likely includes blocking out harassment and verbal abuse from fans. This would then explain why many of the athletes in this study reported being unaffected by fan abuse despite being treated unethically. However, further research is needed to better understand the mechanisms that allow many athletes to become inured to fan abuse.

In contrast, while many athletes may be able to deflect fan abuse and even use it as motivation to play harder, it is important to note that some athletes $(17.6 \%)$ did report being emotionally hurt by malicious fan behavior. A portion of the sample (33.3\%) also indicated that insults and harassment by fans decreased playing ability "somewhat." These responses suggest that perhaps depending on the athlete and the nature of the abuse, that some athletes could be emotionally hurt to a serious degree, which would warrant more attention to the issue of fan behavior in college athletics. Additional quantitative studies are needed with larger stratified samples of women's and men's sports to obtain a clearer understanding of how many athletes are emotionally impacted by fan abuse. In particular, this study was delimited to Division II NCAA athletics, which does not involve the amount of money, commercialization, and expectation to win as Division I athletics (Coakley, 2009; Lumpkin et al., 2003). This in turn, could create a greater prevalence of highly identified fans that exude an even higher level of fan abuse towards athletes at the latter level (see Wann et al., 1999; Wann, Peterson, Cothran, and Dykes, 1999 for studies concerning the relationship between 
team identification and spectator aggression).

\section{Limitations and Future Research}

This study contained a few limitations that should be noted as well as future directions for research. First, the study's sample was limited to NCAA Division II athletes. Considering that reports of spectator aggression have largely come from Division I athletic programs (Gubar, 2015; Monteiro, 2014; Ngo, 2012) which have significantly larger fan bases and revenue production (Lumpkin et al., 2003; Simon et al., 2015), it is possible that Division I athletes would report higher instances of spectator aggression as well as being more emotionally impacted. Additional research with Division I athletes is needed to obtain a clearer understanding of spectator aggression and its impact on athletes.

Second, although the emotional impact of the spectator aggression was assessed on a variety of men's and women's sports, the sample size did not allow for meaningful comparisons across sports. Future research is needed with larger stratified samples of various men's and women's sports to investigate any differences in spectator aggression. Certain sports may have more of a spectator aggression problem than others, which may suggest something about sport culture.

Third, it was noted that Wann et al.(1999) posited that spectators may act aggressively for either hostile or instrumental reasons. However, this study did not assess aggression at the level of intentionality. Therefore, it is not known if the types of spectator aggression reported by athletes were done hostilely or instrumentally or for any other particular reason. Additional studies are needed to determine the reasons for sport spectator aggression.

Fourth, this study did not ask the athlete participants to provide reasons for why they were or were not emotionally hurt by spectator aggressions. It was speculated in the discussion that perhaps athletes are socialized by the sport milieu to shut out the aggressive nature of spectators. Additional studies, particularly qualitative, are needed to obtain a deeper understanding of how athletes cope with spectator aggression.

\section{Conclusion}

Although the majority of athletes in this study's sample did not report being emotionally hurt by various forms of spectator aggression, it does not necessarily nullify spectator aggression as a moral issue. As mentioned in the discussion, it is possible that many college or elite level athletes have been socialized into deflecting the effects of spectator aggression. However, the development of a protective shield from harm does not make it morally acceptable to attempt to cause such harm (e.g., make comments about players' physical appearance or playing ability). Furthermore, there was a portion of athletes $(17.6 \%)$ that did report being emotionally hurt by spectator aggression. Thus, not all 
athletes are impervious to spectator aggression.

Some readers may feel that sport spectators who yell statements such as "great job 7," "nice one," "air ball," or just generally laughing and jeering at mistakes is not worthy of moral concern. To the contrary, it is suggested that whether it is yelling "air ball" or telling a player "you suck," that both forms are discordant with morality and ethical thinking. This argument can be supported by Immanuel Kant's categorical imperative, which is comprised of the tenets of universality and respect (DeSensi \& Rosenberg, 1996; Frankena 1973).

Applied to sport spectators, Kant's principle of universality requires aggressive sport spectators to consider if they are willing to universalize their aggressive actions. In other words, are they willing to recommend that their aggressive actions would be good for everyone to do as well if done to their own self? For example, would a spectator who tells an opposing player that they "suck" because they are angry (hostile aggression) or because they want to help their team win (instrumental aggression) be willing to suggest that such actions are good for anyone who is angry or needs to achieve something they desire. More than this, would the spectator be willing to approve of aggressive actions done to their own self? That is, would they want to be told that they "suck" or be criticized for their physical appearance simply because someone feels like telling them so. The answer to this question is likely, "No."

Kant's second component of his categorical imperative, respect, may also be applied to spectator aggression. Kant posited that all human beings should be treated as ends rather than a means to an end (DeSensi \& Rosenberg, 1996). In the latter form, one is not respecting individuals as rationally thinking and autonomous persons who have the freedom to choose their thoughts and course of action. Rather one is being thought of as a means to achieve a particular end result, regardless of their freedom of choice. In the case of aggressive sport spectators, opposing players are treated as a means to an end when sport spectators inflict aggressive forms of behavior in order to diminish the player's competitive level (and help their team win) or be used as a vehicle for the spectator to vent anger and frustration.

In addition to ethics, it is important to consider how this study's findings are inconsistent with sportsmanship. As mentioned earlier, sportsmanship involves moral values such as fairness, respect, and amicability (Arnold, 1994; Clifford \& Feezell, 1997; Rudd \& Stoll, 1998). Clearly, sport spectators who criticize opposing players for their ability or physical appearance, or who make sarcastic comments such as "Nice job, 7," are not in harmony with the ideals of sportsmanship. Therefore, again, although many of the athletes did not report being emotionally hurt by spectator aggression, the kinds of 
aggressive actions that were reported are arguably a violation of sportsmanship.

Ultimately, the data from this study allows for the argument to be made that many sport spectators are acting in an aggressive manner that is both unethical and unsportsmanlike. Further, although, many of the athletes indicated that the aggressive behavior is not hurtful, it does mean that concern is unwarranted. And, in fact, concern has indeed been shown by the NCAA in establishing the Committee on Sportsmanship and Ethical Conduct to help develop positive sportsmanship environments for all involved at collegiate athletic events (Sportsmanship and Ethical Conduct, n.d.).

Notably, some schools have begun responding to the committee's charge. For example, the Indiana University Athletic Department now places "Courtside Seating Guidelines" in the floor level seating of Assembly Hall gymnasium (basketball). The guidelines provide a list of proscriptive behaviors and consequences for engaging in them (Machir, 2014). The Michigan State Department of Intercollegiate Athletics has a fan behavior policy that states, "Any individual who engages in unruly or illegal conduct at an athletic event may be ejected from the event and prohibited from reentering the athletic event." ("Season Ticket Holder Policy," n.d., n.p.)

Thus, there is evidence that in some quarters there is recognition of the spectator aggression problem. However, spectator behavior policies involving the revoking of tickets or removal of spectators from seats may only be one piece of the intervention picture. Lickona (1991) postulated that the possession of character involves the qualities of moral knowing, moral feeling, and moral action. Applied to sportsmanship, this means that sport spectators must have a knowing and valuing of sportsmanship in order to practice it. By arguing that spectator aggression is a moral issue that belies the concept of sportsmanship, it is hoped there will more increased efforts within college athletic departments and organizations to not only develop spectator policies but to also foster the moral knowing and valuing of sportsmanship. 


\section{References}

Arnold, P. J. (1984). Three approaches toward an understanding of sportsmanship. Journal of the Philosopby of Sport, X, 61-70

Arnold, P. J. (1992). Sport as a valued human practice: A basis for the consideration of some moral issues in sport. Journal of Philosophy of Education, 26(2), 237-255.

Baron, R. A., \& Richardson, D. R. (1994). Human aggression (2nd ed.). New York: Plenum Press.

Brand, M. (2008, December 12 ). Getting a grip on fan behavior in college sports. The Huffington Post.

Branscombe, N. R., \& Wann, D. L. (1992). Role of identification with a group, arousal, categorization processes, and self-esteem in sports spectator aggression. Human Relations, 45(10), 1013-1033.

Champions of Character. National Association of Intercollegiate Athletics. Retrieved from http://www.naia.org/SportSelect.db ml?\&\&DB_OEM_ID $=27900 \& S P I D$ $=117008 \&$ SPSID $=700608$

Clifford, C., \& Feezell, R. M. (1997). Coaching for character. Champaign, IL: Human Kinetics.

Coakley, J. (2009). Sports in society (10 ${ }^{\text {th }}$ ed.). Boston, MA: McGraw-Hill.

DeSensi, J. T., \& Rosenberg, D. (1996). Ethics in sport management. Morgantown, WV: Fitness Information Technology, Inc.
Eitzen, S. D. (1999). Fair and Foul: Beyond the myths and paradoxes of sport. Lanham, MD: Rowman \& Littlefield Publishers, Inc.

Fraleigh, W. (1982). Why the good foul is not good. In W. J. Morgan \& K. V. Meier (Eds.), Philosophic inquiry in sport (pp. 185-87). Champaign, IL: Human Kinetics.

Frankena, W. K. (1973). Ethics (2nd ed.). Englewood, NJ: Prentice-Hall, Inc.

Frary, R. B. (n.d.). A brief guide to questionnaire development. Retrieved from http://ericae.net/ft/tamu/vpiques3. htm

Gubar, J. (2015). Fanaticus: Mischief and madness in the modern sports fan. Lanham, MD: Rowman \& Littlefield Publishing Group, Inc.

Johnson, B., \& Christensen, L. (2012). Educational research: Quantitative, qualitative, and mixed approaches (4th ed.). Thousand Oaks, CA: Sage Publications.

Lickona, T. (1991). Educating for character. New York: Bantam Books. Lumpkin, A., Stoll, S. K., \& Beller, J. M. (1994). Spot etbics: Applications for fair play. St. Louis, MO: Mosby-Year Book, Inc.

Lumpkin, A., Stoll, S. K., \& Beller, J. M. (2003). Spot ethics: Applications for fair play. New York: McGraw-Hill.

National Collegiate Athletic Association core values. National Collegiate Athletic Association. Retrieved from 
http://www.ncaa.org/about/ncaacore-values

NCAA game day environment and fan code of conduct. National Collegiate Atbletic Association. Retrieved from http://www.ncaa.org/sites/default/f iles $/$ Fan $\% 2 B C o d e \% 2 B o f \% 2 B C o n d u$ ct.pdf

Machir, T. (2014, February 12). Indiana take proactive approach to courtside fan behavior. Sporting News. Retrieved from

http://www.sportingnews.com/

May, R. A. B. (2001). The sticky situation of sportsmanship: Contexts and contradictions in sportsmanship among high school boys basketball players. Journal of Sport \& Social Issues, 25(4), 372-389.

Monteiro, L. (2014, February 11). Bad behavior at sporting events continues on. Sportsology. Retrieved from http://www.sportsology.com/conten t/bad-behavior-sporting-eventscontines

Morgan, W. J., Meier, K. V., \& Schneider, A. J. (Eds.). (2001). Ethics in sport. Champaign, IL: Human Kinetics.

Ngo, M. (2012, November 19). Rude college sports fans ruin experience for the rest, give new meaning to hostile environment. Iowa Center for Public Affairs Journalism. Retrieved from http://iowawatch.org/2012/11/19

O'Hanlon, T. (1980). Interscholastic athletics, 1900-1940: Shaping citizens for unequal roles in the modern industrial state. Educational Theory, 30(2), 89-103.

Patton, M. Q. (1987). How to use qualitative methods in evaluation. Newbury Park, CA: Sage Publications, Inc.

Pearson, K. M. (1973). Deception, sportsmanship, and ethics. In W. J. Morgan \& K. V. Meier (Eds.), Philosophic inquiry in sport (pp. 183184). Champaign, IL: Human Kinetics.

Rudd, A. (2008). A qualitative study on the moral reasoning of college athletes. Journal of Coaching Education, 1(1) 1-27.

Rudd, A. (2016). Do sport spectators have limits on their aggressive behavior? Journal of Contemporary Athletics, 10(3), 177-184.

Rudd, A., \& Gordon, B (2010). An exploratory investigation of sportsmanship attitudes among college student basketball fans. Journal of Sport Behavior, 33(4), 466-488.

Rudd, A., \& Stoll, S.K. (1998).

Understanding sportsmanship. Journal of Physical Education, Recreation \& Dance, 69 (9), 38-42.

Sage, G. H., \& Eitzen, D. S. (2016). Sociology of North American Sport (10th ed.). New York: Oxford University Press. Season ticket holder policy. Michigan State University Athletic Department. Retrieved from http://www.msuspartans.com/auto_ pdf/p_hotos/s_chools/msu/genrel/ auto_pdf/fan-behaviour-policy 
Shields, D., \& Bredemeier, B. (1995).

Character development and physical activity. Champaign, IL: Human Kinetics.

Simon, R. L., Torres, C. R., \& Hager, P. F. (2015). Fair play: The ethics of sport (4th ed.). Boulder, CO: Westview Press. Sportsmanship and Ethical Conduct. (n.d.). Retrieved December 8, 2009, from http://www.ncaa.org/wps/wcm/con nect/ncaa/ncaa/legislation+and+gov ernance/eligibility+and + recruiting/s portsmanship/2009/index.html

The case for high school activities. National

Federations of State High School Associations. Retrieved from https://www.nfhs.org/articles/thecase-for-high-school-activities /

Thorndike, R. M. (1997). Measurement and evaluation in psychology and education (6th Upper Saddle River, NJ: PrenticeHall.

UTSA hires LSU's Wilson to replace Coke; Texas state taps James Madison's Withers. Collegefootballpoll.com. (2015, January). Retrieved from http://www.collegefootballpoll.com/ coaching_changes.html

Wahl, G. (2008, February 26). Extreme vulgarity and taunting by college basketball fans this season raise the question: How much is too much? For schools and conferences, it's time to act. SI On Campus.com. Retrieved 15, 2008, from http://sportsillustrated.cnn.com/200 8/sioncampus/02/26/abusive.fans03 03/index.html
Wakefield, K. L., \& Wann, D. L. (2006). An examination of dysfunctional sport fans: Method of classification and relationships with problem behaviors. Journal of Leisure Research, 38, 168-186. Wann, D. L., \& Branscombe, N. R. (1993). Sports fans: Measuring degree of identification with their team. International Journal of Sport Psychology, 24, 1-17.

Wann, D. L., Carlson, J. D., \& Schrader, M. P. (1999). The impact of team identification on the hostile and instrumental verbal aggression of sport spectators. Journal of Social Behavior and Personality, 14, 279-286.

Wann, D. L., Haynes, G., McLean, B., \& Pullen, P. (2003). Sport team identification and willingness to consider anonymous acts of hostile aggression. Aggressive Behavior, 29, 406-413.

Wann, D. L., Melnick, M. J., Russell, G. W., \& Pease, D. G. (2001). Sport fans: The psychology and social impact of spectators.

New York: Routledge.

Wann, D. L., Peterson, R. R., Cothran, C., \& Dykes, M. (1999). Sport fan aggression and anonymity: The importance of team identification. Social Behavior and Personality, 27(6), 597-602. 


\section{Tables}

Table 1

Division II Athletes Responses to Quantitative Questions 1-5

\begin{tabular}{|c|c|c|c|c|}
\hline Question & Response & Response & Response & Total \\
\hline $\begin{array}{l}\text { Q1. Harassed } \\
\text { by spectators } \\
\text { while playing }\end{array}$ & $\begin{array}{ll} & \text { No } \\
(57) & (52.8 \%)\end{array}$ & $\begin{array}{c}\text { Yes } \\
(51)(47.2 \%)\end{array}$ & & 108 \\
\hline $\begin{array}{l}\text { Q2. How often } \\
\text { insulted or } \\
\text { harassed by } \\
\text { spectators }\end{array}$ & $\begin{array}{l}\text { Not often } \\
(37)(72.5 \%)\end{array}$ & $\begin{array}{c}\text { Often } \\
(13)(25.5 \%)\end{array}$ & $\begin{array}{l}\text { Very Often } \\
\text { (1) }(2.0 \%)\end{array}$ & 51 \\
\hline $\begin{array}{l}\text { Q3. Extent } \\
\text { insults or } \\
\text { harassment } \\
\text { hurt } \\
\text { emotionally }\end{array}$ & $\begin{array}{l}\text { Not Hurtful } \\
(42)(82.4 \%)\end{array}$ & $\begin{array}{c}\text { Hurtful } \\
\text { (9) }(17.6 \%)\end{array}$ & $\begin{array}{l}\text { Very Hurtful } \\
\qquad(0)(0 \%)\end{array}$ & 51 \\
\hline $\begin{array}{l}\text { Q4. Extent } \\
\text { insults or } \\
\text { harassment } \\
\text { decrease } \\
\text { playing ability }\end{array}$ & $\begin{array}{c}\text { Not at all } \\
(34)(66.7 \%)\end{array}$ & $\begin{array}{l}\text { Somewhat } \\
\text { (17) }(33.3 \%)\end{array}$ & $\begin{array}{l}\text { A lot } \\
(0)(0 \%)\end{array}$ & 51 \\
\hline $\begin{array}{l}\text { Q5. Extent } \\
\text { insults or } \\
\text { harassment } \\
\text { improve } \\
\text { performance }\end{array}$ & $\begin{array}{c}\text { A lot } \\
\text { (8) }(15.7 \%)\end{array}$ & $\begin{array}{l}\text { Somewhat } \\
\text { (29) }(56.9 \%)\end{array}$ & $\begin{array}{l}\text { Not at all } \\
\text { (14) (27.5) }\end{array}$ & 51 \\
\hline
\end{tabular}

Note: The total number of responses dropped from 108 (all respondents) to 51 because the latter are only those that said "yes" to question \#1. 